\title{
PENDEKATAN MATEMATIKA REALISTIK UNTUK MENINGKATKAN KEMAMPUAN BERPIKIR MATEMATIS SISWA
}

\author{
Nurmudi \\ SMP Negeri 2 Giriwoyo \\ Email : nurmudisapawi@yahoo.co.id
}

\begin{abstract}
The purpose of this study is to improve students' mathematical thinking skills using a realistic mathematical approach. The research is a Classroom Action Research (CAR) conducted collaboratively and participatively. The subject of the research was the students of class VIII B, State Junior High School 2 Giriwoyo, in the academic year 2017/2018 with 32 students. While the object of research is the whole process of learning mathematics through the application of a realistic mathematical approach implemented in class VIII B of SMP Negeri 2 Giriwoyo. Based on data obtained from observations, field notes, questionnaires, interviews, tests of cycle I and cycle II, as well as documentation, the researcher concludes that mathematics learning activities through the application of a realistic mathematical approach in class VIII B of SMP Negeri 2 Giriwoyo are carried out according to plans that have been prepared. In addition, the purpose of the action taken is to improve students' mathematical thinking abilities achieved.
\end{abstract}

Keywords: Realistic Mathematics Approach, Mathematical Thinking Ability

\section{PENDAHULUAN}

Pendidikan memiliki peran yang sangat penting dalam proses peningkatan kualitas sumber daya manusia. Hal ini sejalan dengan pernyataan Sumitro, dkk (2006: 17) yang menyatakan bahwa pendidikan adalah proses pengembangan kemampuan dan perilaku manusia secara keseluruhan. Selanjutnya diungkapkan pula bahwa pendidikan berguna untuk mengembangkan nilai-nilai baru yang dipandang sesuai oleh masyarakat dalam menghadapi tantangan ilmu, teknologi dan dunia modern (Sumitro, dkk., 2006: 19). Oleh karena itu dunia pendidikan diharapkan bisa menjadi salah satu wahana untuk mempersiapkan generasi bangsa, sehingga lahir sumber daya manusia yang handal dan mempunyai kemampuan untuk menghadapi dinamika perkembangan ilmu pengetahuan dan teknologi saat ini secara cepat, tepat dan efektif.

Pakar pendidikan matematika, seperti Frederick H. Bell dan Erman Suherman menyebutkan bahwa matematika merupakan ratu dari segala disiplin ilmu. Frederick H. Bell (1981: 23) menyebutkan bahwa "Mathematics has been called the queen of science. Mathematics has been an accurate and indispensable tool in social, economic, and technological development". Hal tersebut berarti matematika menjadi suatu alat yang akurat dan tidak dapat dilepaskan dalam perkembangan ilmu pengetahuan lain seperti dalam ilmu sosial, ekonomi, dan teknologi. Menurut Erman Suherman, dkk (2003: 25) matematika sebagai ratu atau ibunya ilmu dimaksudkan bahwa matematika adalah sebagai sumber dari ilmu yang lain. Dengan kata lain, banyak ilmu-ilmu yang penemuan dan pengembangannya didukung oleh matematika. Seiring dengan berkembangnya ilmu pengetahuan dan teknologi yang semakin meningkat, peran matematika sebagai salah satu ilmu dasar yang mempunyai nilai esensial dalam berbagai bidang kehidupan menjadi sangat penting. Konsep matematika yang 
telah dimiliki bukan satu-satunya faktor pendukung ilmu pengetahuan, namun pola pikir matematis juga memberikan kontribusi yang cukup besar dalam perkembangan ilmu pengetahuan. Sebagai contoh seperti yang disebutkan Erman Suherman, dkk (2003: 25-26), yaitu: penemuan dan pengembangan teori-teori dalam fisika dan kimia melalui konsep kalkulus, teori Mendel dalam biologi dikembangkan melalui konsep probabilitas, serta teori ekonomi mengenai permintaan dan penawaran melalui konsep fungsi dan kalkulus tentang differensial dan integral.

Matematika diajarkan mulai dari jenjang sekolah dasar sampai dengan perguruan tinggi. Matematika mempunyai banyak kegunaan. Beberapa kegunaan matematika sederhana yang praktis, menurut Ruseffendi (2006: 208), yaitu:

a. Dengan belajar matematika kita mampu berhitung dan mampu melakukan perhitunganperhitungan lainnya.

b. Matematika merupakan persyaratan untuk beberapa mata pelajaran lainnya.

c. Dengan belajar matematika perhitungan menjadi lebih sederhana dan praktis.

d. Dengan belajar matematika diharapkan kita mampu menjadi manusia yang berpikir logis, kritis, tekun, bertanggung jawab dan mampu menyelesaikan persoalan.

Berdasarkan kegunaan matematika yang diungkapkan Ruseffendi tersebut, menunjukkan bahwa matematika perlu dipelajari oleh peserta didik mulai dari sekolah dasar untuk membekali kemampuan berpikir logis, analitis, sistematis, kritis, dan kreatif, serta kemampuan bekerjasama.

Tujuan pembelajaran matematika, yaitu:

a. Melatih cara berpikir dan bernalar dalam menarik kesimpulan, misalnya melalui kegiatan penyelidikan, eksplorasi, eksperimen, menunjukkan kesamaan, perbedaan, konsisten dan inkonsistensi.

b. Mengembangkan aktivitas kreatif yang melibatkan imajinasi, intuisi, dan penemuan dengan mengembangkan pemikiran divergen, orisinil, rasa ingin tahu, membuat prediksi dan dugaan, serta mencoba-coba.

c. Mengembangkan kemampuan pemecahan masalah.

d. Mengembangkan kemampuan menyampaikan informasi atau mengkomunikasikan gagasan antara lain melalui pembicaraan lisan, catatan, grafik, peta, dan diagram (Balitbang Depdiknas, 2003: 6).

Berdasarkan uraian tentang tujuan pembelajaran matematika tersebut, menunjukkan bahwa pembelajaran matematika adalah: (1) proses membelajarkan siswa agar memiliki kemampuan untuk berpikir matematis, (2) mengembangkan kemampuan dan keterampilan matematika siswa agar mampu menerapkan pola pikir matematika dalam kehidupan sehari-hari dan dalam mempelajari ilmu pengetahuan yang lain.

James M. Royer (2003: 47), menyatakan bahwa "Children are actively constructing mathematics as function of their mathematical experiences". Dengan kata lain anak-anak aktif membangun pola matematika berdasarkan pengalaman matematika mereka. Untuk memahami konsep-konsep matematika yang abstrak, siswa masih memerlukan visualisasi atau hal-hal yang nyata bagi siswa. Hal ini berdasarkan pernyataan Sutarto Hadi (2002: 32) yang menyebutkan bahwa "The real world is used as a starting point for the development of mathematical concept and ideas". Selanjutnya Sutarto Hadi (2002: 32) menjelaskan pula bahwa "The real world here is the world that is concrete for students". Dengan kata lain, dunia 
nyata atau hal-hal yang konkret bagi siswa digunakan sebagai titik awal dalam pengembangan konsep dan ide-ide matematika.

Salah satu pendekatan yang berorientasi pada permasalahan-permasalahan yang nyata bagi siswa adalah pendekatan matematika realistik. Pendekatan ini mengacu pada Realistic Mathematics Education (RME) yang dikembangkan oleh Freudenthal di Belanda (R.K. Sembiring, 2008: 60). Freudenthal menyatakan bahwa pembelajaran matematika sebaiknya berangkat dari aktifitas manusia, karena mathematics is a human activity (Erman Suherman, dkk., 2003: 146). Dengan kata lain pendekatan matematika realistik merupakan pendekatan yang bertolak dari matematisasi pengalaman sehari-hari dan menerapkan matematika dalam pengalaman sehari-hari. Menurut Hammad Fithry Ramadhan (2009: 1) bahwa paradigma baru dalam pembelajaran sekarang ini, khususnya pembelajaran matematika realistik menekankan terhadap proses pembelajaran dimana aktivitas siswa dalam mencari, menemukan dan membangun sendiri pengetahuan yang mereka perlukan benar-benar menjadi pengalaman belajar tersendiri bagi setiap individu. Diungkapkan pula oleh Marpaung (2009: 1) bahwa dengan pendekatan matematika realistik: (1) matematika bukan lagi sebagai mata pelajaran yang menakutkan bagi siswa, (2) matematika sudah menjadi pelajaran yang menyenangkan, (3) proses pembelajaran tidak lagi bersifat satu arah.

Melatih berpikir dan bernalar dalam pembelajaran matematika sangatlah penting. Erman Suherman, dkk (2003: 18) menyatakan bahwa dengan matematika kita dapat berlatih berpikir secara logis. Selanjutnya diterangkan pula bahwa tujuan umum pembelajaran matematika pada jenjang pendidikan dasar dan menengah adalah memberikan penekanan pada penataan nalar dan pembentukan sikap siswa (Erman Suherman, dkk., 2003: 58). Menurut Ruseffendi (2006: 148), sebagian anak SMP di negara Indonesia belum masuk ke dalam tahap operasi formal, sehingga dalam pembelajaran matematika khususnya pada jenjang sekolah dasar dan sekolah menengah pertama masih diperlukan pola pikir induktif.

Berpikir matematis atau mathematical thinking perlu untuk diajarkan. Hal ini merujuk pada pendapat Shigeo Katagiri (2004: 4) yang menyatakan bahwa "The most important ability that arithmetic and mathematics courses need to cultivate in order to instill in students to think and make judgment independently is mathematical thinking". Dengan kata lain berpikir matematis merupakan kemampuan utama dalam perhitungan dan pelajaran matematika, yang perlu diolah untuk menanamkan pada siswa dalam berpikir dan menentukan keputusan secara mandiri. Selanjutnya Shigeo Katagiri (2004: 5) juga mengungkapkan bahwa "Mathematical thinking allows for: (1) an understanding of the necessity of using knowledge and skills, (2) learning how to learn by oneself, and the attainment of the abilities required for independent learning". Dengan kata lain, berpikir matematis memberikan pemahaman akan pentingnya pengetahuan atau pemahaman konsep matematika dan kemampuan dalam memecahkan permasalahan matematika, serta belajar bagaimana belajar sendiri dan mencapai kemampuan yang dibutuhkan dalam belajar mandiri.

Berdasarkan hasil wawancara dan koordinasi peneliti dengan guru-guru matematika kelas VIII SMP Negeri 2 Giriwoyo peneliti melakukan koordinasi dengan guru matematika kelas VIII SMP Negeri 2 Giriwoyo dan diperoleh informasi bahwa dalam melaksanakan pembelajaran matematika, guru sudah menyusun perangkat-perangkat pembelajaran seperti rencana pelaksanaan pembelajaran dan silabus. Didapatkan informasi juga bahwa dalam pelaksanaan pembelajaran matematika, guru masih sering menggunakan metode ceramah dan tanya jawab. Alat peraga yang dimiliki sekolah hanya sesekali saja digunakan dalam pembelajaran matematika. Siswa kelas VIII dibagi dalam tiga kelas dengan jumlah murid tiap kelas rata-rata 32 siswa dengan kemampuan yang setara antar kelas. 
Pada saat pembelajaran matematika berlangsung di kelas. Dalam pembelajaran yang berlangsung, siswa-siswa cukup antusias mengikuti penjelasan dari guru. Materi yang disampaikan pada pertemuan tersebut adalah mengenai fungsi, termasuk bagaimana menentukan banyaknya fungsi yang mungkin dari dua himpunan yang sudah diketahui banyak anggotanya. Sebelum materi tentang fungsi, siswa-siswa sudah mempelajari materi tentang relasi dengan mengerjakan tugas yang diberikan pada pertemuan sebelumnya dan belum diterangkan oleh guru. Sebagian siswa sudah mampu mengerjakan tugas tersebut, namun sebagian yang lain masih mengalami kesulitan dalam memahami materi relasi. Siswa-siswa cenderung tidak mau bertanya langsung ketika mengalami kesulitan. Mereka mau menjawab pertanyaan jika ditunjuk oleh guru. Langkah-langkah pembelajaran dalam menentukan banyaknya fungsi yang mungkin dari dua himpunan yang diketahui banyak anggotanya, adalah: (1) guru membimbing siswa melalui contoh himpunan-himpunan dengan jumlah anggota yang sedikit, (2) siswa disuruh untuk menentukan semua kemungkinan gambar fungsi dari dua himpunan yang telah ditentukan banyak anggotanya tersebut. Sebagian siswa berhasil menemukan, namun sebagian lagi belum berhasil. Di akhir pembelajaran, guru bersama siswa menarik kesimpulan mengenai rumus untuk menentukan banyaknya fungsi dari dua himpunan yang diketahui banyak anggotanya.

Peneliti melakukan observasi kelas kembali saat pembelajaran matematika kelas VIII berlangsung. Pada pertemuan tersebut, pembelajaran diisi dengan latihan soal-soal mengenai materi yang telah dipelajari pada pertemuan sebelumnya, yaitu tentang fungsi. Sub materi yang termasuk dalam materi fungsi adalah istilah-istilah dalam fungsi dan menentukan banyaknya fungsi dari dua himpunan yang diketahui banyak anggotanya. Soal-soal yang diberikan pada siswa sudah diberi variasi, tidak seperti soal-soal pada contoh. Soal-soal berupa soal uraian. Variasi soal yang diberikan yaitu pada unsur yang diketahui ataupun unsur yang ditanyakan dari soal. Dalam mengerjakan soal-soal, sebagian besar siswa menggunakan langkah-langkah seperti contoh yang sudah diberikan. Pada saat mengerjakan soal yang sedikit berbeda dengan contoh, siswa mengalami kesulitan karena belum paham maksud dari soal dan bagaimana langkah penyelesaian yang harus mereka lakukan. Ketika siswa disuruh menyampaikan alasan mengenai jawaban yang mereka dapatkan, tidak semua siswa mampu memberikan alasan mereka, meskipun jawaban yang mereka dapatkan adalah benar.

Pada Saat Proses Belajar Mengajar, peneliti juga melakukan observasi selanjutnya. Materi yang disampaikan pada pertemuan tersebut adalah mengenai notasi fungsi. Dalam mengerjakan soal-soal mengenai materi tersebut, siswa-siswa diharapkan mampu menentukan notasi dari suatu fungsi dengan aturan yang telah ditentukan, range dari suatu fungsi, dan nilai suatu fungsi. Setelah siswa mengerjakan soal-soal yang diberikan, beberapa siswa maju ke depan untuk menuliskan jawaban mereka di papan tulis. Namun bukan atas inisiatif dari siswa, melainkan ditunjuk terlebih dahulu oleh guru. Ketika ada yang memiliki jawaban berbeda, mereka tidak ada yang menyampaikannya ataupun bertanya pada guru.

Pada pembelajaran berlangsung mandiri, karena guru pengampu sedang ada tugas di luar sekolah. Sehingga hanya peneliti tanpa guru pengampu yang mendampingi belajar siswa. Siswa diberi tugas untuk mempelajari dan mengerjakan latihan mengenai materi menentukan bentuk fungsi. Dari pengamatan peneliti, diketahui bahwa sebagian besar siswa masih mengalami kesulitan dalam memahami materi pada buku panduan yang digunakan secara mandiri tanpa penjelasan dari guru. Hal ini terbukti pada saat mereka mengerjakan soal-soal yang sudah tersedia. Jika mereka menemukan soal yang sama seperti contoh yang sudah tersedia, mereka mampu menyelesaikannya, namun jika soal sudah diberi sedikit variasi mereka mengalami kesulitan. Proses belajar yang berlangsung tidak setertib seperti saat 
didampingi oleh guru pengampu. Hal ini menunjukkan kemandirian belajar siswa masih kurang.

Dari hasil proses pembelajaran matematika di SMP Negeri 2 Giriwoyo, peran aktif siswa masih perlu ditingkatkan. Hal ini dibuktikan dari hasil pengamatan peneliti pada saat proses pembelajaran matematika di kelas VIII. Siswa cenderung mau menjawab pertanyaan jika ditunjuk oleh guru. Selanjutnya dalam menjawab pertanyaan mengenai materi yang sudah dipelajari, siswa masih mengalami kesulitan dalam mengaplikasikan pada soal. Hal ini dibuktikan dari jawaban hasil pekerjaan siswa kelas VIII tentang materi fungsi atau pemetaan, sebagian jawaban siswa menunjukkan bahwa gambar diagram panah yang mereka gambarkan untuk membuktikan banyaknya fungsi dari dua himpunan, bukanlah suatu fungsi. Meskipun siswa mampu menjawab pengertian dari fungsi dan mampu menunjukkan rumus untuk menentukan banyaknya fungsi dari dua himpunan.

Dari hasil diskusi peneliti dengan guru setelah diadakan observasi pembelajaran di kelas, diperoleh informasi bahwa kemampuan berpikir matematis siswa kelas VIII dirasa masih perlu ditingkatkan, karena meskipun siswa paham dengan konsep matematika namun kadang mereka masih kesulitan dalam mengaplikasikan untuk menyelesaikan suatu persoalan. Selain itu, mereka juga mengaku bahwa ketika guru memberikan materi baru, mereka terkadang lupa dengan materi yang sudah diberikan sebelumnya. Berdasarkan pertimbangan dari guru matematika kelas VIII, maka kelas VIII B ditentukan sebagai kelas yang digunakan untuk penelitian tindakan kelas. Selanjutnya peneliti mengadakan tes awal untuk mengetahui kemampuan berpikir matematis siswa kelas VIII B. Dari hasil tes awal yang telah dilaksanakan, didapat hasil bahwa persentase rata-rata skor yang diperoleh siswa adalah $48,89 \%$, hal tersebut menunjukkan kemampuan berpikir matematis siswa masih rendah sehingga perlu untuk ditingkatkan.

Melihat uraian di atas, maka peneliti memandang perlu adanya upaya meningkatkan kemampuan berpikir matematis siswa untuk mencapai tujuan pembelajaran matematika secara optimal melalui penerapan pendekatan matematika realistik.

\section{METODE PENELITIAN}

\section{a. Jenis Penelitian}

Penelitian merupakan Penelitian Tindakan Kelas (PTK) yang dilakukan secara kolaboratif dan partisipatif. Kolaboratif artinya peneliti berkolaborasi dengan guru matematika kelas VIII SMP Negeri 2 Giriwoyo Partisipatif artinya peneliti yang dibantu oleh rekan-rekan Guru terlibat secara langsung di dalam penelitian. Pada tahap awal guru dan peneliti mendiskusikan permasalahan penelitian dan menentukan rencana tindakan yaitu upaya untuk meningkatkan kemampuan berpikir matematis siswa melalui pendekatan matematika realistik. Dalam penelitian ini peneliti menggunakan model spiral dari Kemmis dan Mc Taggart. Adapun model penelitian tindakan kelas menurut Kemmis dan Mc Taggart (Norman K. Densin dan Yvonnas S. Lincoln, 2005: 564) disajikan pada gambar berikut: 


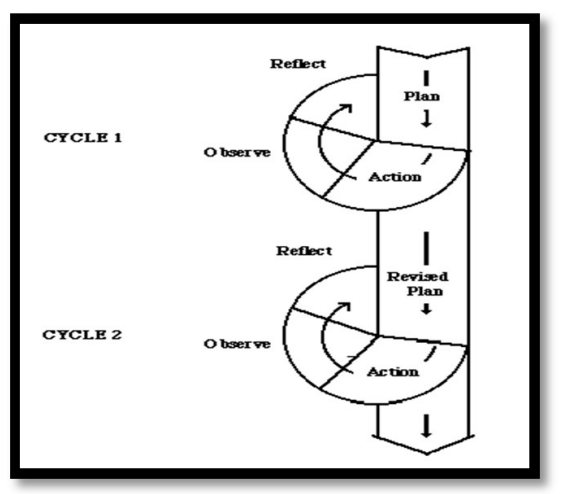

Gambar 1. Model Penelitian Tindakan Kelas (PTK) menurut Kemmis dan Mc Taggart

\section{b. Subjek dan Objek Penelitian}

Subjek penelitian adalah siswa kelas VIII B SMP Negeri 2 Giriwoyo tahun pelajaran 2017/2018 sebanyak 32 siswa. Sedangkan objek penelitian adalah keseluruhan proses pada pembelajaran matematika melalui penerapan pendekatan matematika realistik yang dilaksanakan di kelas VIII B SMP Negeri 2 Giriwoyo

c. Tempat dan Waktu Penelitian

Penelitian dilakukan di SMP Negeri 2 Giriwoyo yang beralamat di Selomarto, Giriwoyo, Wonogiri pada bulan Februari - Maret 2018 dengan menyesuaikan jam pelajaran matematika.

\section{d. Desain Penelitian}

Penelitian ini dirancang dengan menggunakan penelitian tindakan kelas yang terbagi dalam siklus-siklus. Adapun setiap putaran siklus tindakan meliputi perencanaan, pelaksanaan tindakan dan observasi, serta refleksi.

\section{e. Instrumen Penelitian}

Instrumen penelitian yang digunakan untuk mengumpulkan data dalam penelitian ini yaitu Lembar Observasi, Pedoman Wawancara, Angket, Dokumentasi, Catatan Lapangan, dan Soal Tes Siklus.

\section{f. Teknik Pengumpulan Data}

Teknik pengumpulan data dalam penelitian ini dilakukan melalui observasi, wawancara, dokumentasi, pengisian angket oleh siswa, serta diadakannya tes pada akhir siklus.

\section{g. Teknik Analisis Data}

1) Data hasil observasi

Data dari lembar observasi keterlaksanaan pembelajaran dengan pendekatan matematika realistik disajikan secara deskriptif dan dianalisis sebagai berikut: untuk jawaban "ya" diberi skor 1, sedangkan jawaban "tidak" diberi skor 0 (nol). Cara menghitung persentase skor hasil observasi yaitu:

$$
\text { Persentase skor }(\mathrm{P})=\frac{\text { Juml } \quad \text { skor yang diperoleh }}{\text { Jumlah skor maksimum }} \times 100 \%
$$

2) Data angket

Penghitungan Persentase hasil skor angket respon siswa sebagai berikut : 
skor total tiap aspek berpikir matematis yang diperoleh Selur h siswa $x 100 \%$ skor maksimal x jumlah siswa

3) Data dari hasil tes

Hasil tes diperoleh dari tes siklus I dan tes siklus II. Hasil tes akan dianalisis guna mengetahui kemampuan berpikir matematis siswa setelah dilakukan pembelajaran melalui pendekatan matematika realistik. Hasil tes dianalisis berdasarkan pedoman penskoran yang telah dibuat oleh peneliti. Kemudian dihitung rata-rata skor tiap aspek kemampuan berpikir matematis dan rata-rata skor total dari masing-masing tes. Ratarata skor tiap aspek kemampuan berpikir matematis dan rata-rata skor total kemudian dihitung persentasenya. Selanjutnya hasil persentase dari rata-rata skor tersebut dikategorikan sesuai dengan kualifikasi yang dibuat oleh Morris dan Gibbon (1986:142) untuk menarik kesimpulan mengenai peningkatan kemampuan berpikir matematis siswa, sebagaimana tersaji dalam tabel sebagai berikut:

Tabel 3. Kualifikasi Persentase Hasil Skor Tes

\begin{tabular}{|c|c|}
\hline Persentase & Kualifikasi \\
\hline$t>75 \%$ & Tinggi (High) \\
\hline $50 \%<t \leq 75 \%$ & Sedang (Middle) \\
\hline $25 \%<t \leq 50 \%$ & Rendah (Low) \\
\hline$t \leq 25 \%$ & $\begin{array}{c}\text { Sangat Rendah } \\
\text { (Pass/Fail) }\end{array}$ \\
\hline
\end{tabular}

h. Indikator Keberhasilan

1) Persentase rata-rata skor tiap aspek kemampuan berpikir matematis siswa dari hasil tes mengalami peningkatan dari satu siklus ke siklus selanjutnya dan telah mencapai minimal $70 \%$, serta persentase rata-rata skor total kemampuan berpikir matematis siswa dari hasil tes mengalami peningkatan dan termasuk dalam kualifikasi tinggi yaitu lebih dari $75 \%$.

2) Pelaksanaan tindakan pembelajaran matematika melalui penerapan pendekatan matematika realistik telah terlaksana lebih dari 75\% dari RPP yang telah dipersiapkan.

\section{HASIL PENELITIAN DAN PEMBAHASAN}

Hasil penelitian tindakan kelas yang telah dilaksanakan meliputi hasil tes siklus I, hasil tes siklus II, hasil observasi, hasil angket, dan hasil wawancara dengan siswa.

a. Hasil Tes

Persentase rata-rata skor tes siklus I dan tes siklus II berdasarkan aspek kemampuan berpikir matematis siswa dapat dilihat pada tabel sebagai berikut:

Tabel 4. Persentase Rata-Rata Skor Tes Siklus I dan Siklus II Berdasarkan Aspek Kemampuan Berpikir Matematis Siswa

\begin{tabular}{|l|l|c|c|c|}
\hline No. & Aspek Kemampuan Berpikir Matematis & Siklus I & Siklus II & Peningkatan \\
\hline 1. & Berpikir induktif & $87,69 \%$ & $87,88 \%$ & $0,19 \%$ \\
\hline 2. & Berpikir analog & $67,50 \%$ & $82,75 \%$ & $15,25 \%$ \\
\hline 3. & Berpikir deduktif & $72,89 \%$ & $79,20 \%$ & $6,31 \%$ \\
\hline 4. & Berpikir integratif & $58,80 \%$ & $83,27 \%$ & $24,47 \%$ \\
\hline 5. & Berpikir pengembangan & $70,75 \%$ & $86,00 \%$ & $15,25 \%$ \\
\hline 6. & Berpikir abstrak & $43,10 \%$ & $86,75 \%$ & $43,65 \%$ \\
\hline
\end{tabular}


Pendekatan Matematika Realistik Untuk Meningkatkan Kemampuan Berpikir Matematis Siswa

Nurmudi

\begin{tabular}{|l|l|c|c|c|}
\hline 7. & Berpikir penyederhanaan & $78,27 \%$ & $95,90 \%$ & $17,63 \%$ \\
\hline 8. & Berpikir pengambilan kesimpulan & $52,50 \%$ & $83,20 \%$ & $30,7 \%$ \\
\hline 9. & $\begin{array}{l}\text { Berpikir hal-hal khusus (kemampuan } \\
\text { mengerjakan soal) }\end{array}$ & $21 \%$ & $72,75 \%$ & $51,75 \%$ \\
\hline 10. & Berpikir simbolik & $50,60 \%$ & $76,00 \%$ & $25,4 \%$ \\
\hline 11. & $\begin{array}{l}\text { Berpikir yang berkaitan dengan bilangan, } \\
\text { besaran, dan bentuk }\end{array}$ & $56,40 \%$ & $75,92 \%$ & $19,52 \%$ \\
\hline
\end{tabular}

Tabel tersebut menunjukkan adanya peningkatan persentase rata-rata skor pada tiap aspek kemampuan berpikir matematis siswa. Berikut juga disajikan grafik perbandingan hasil skor tes siklus I dan siklus II:

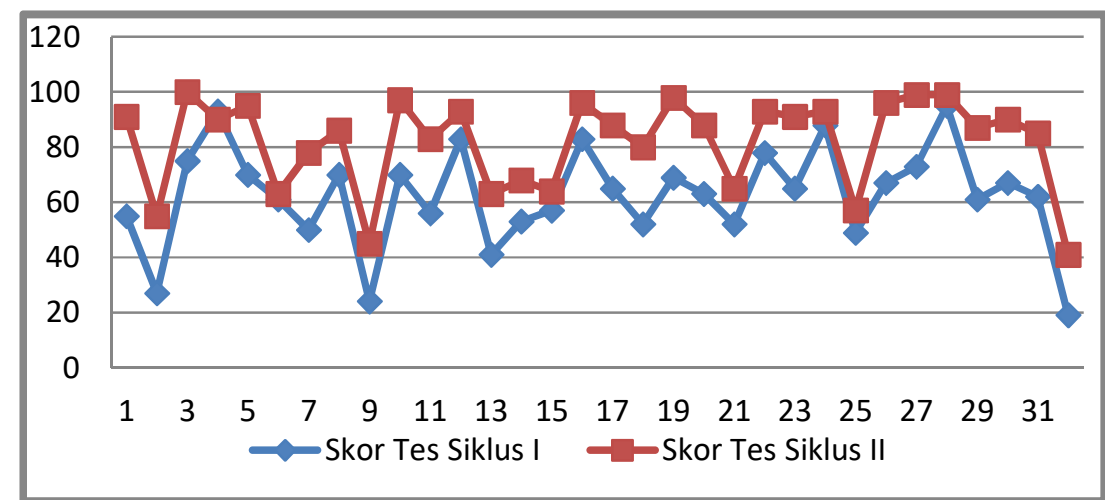

\section{Gambar 1. Grafik Perbandingan Skor Tes Siklus I dan Siklus II}

Selanjutnya, persentase rata-rata skor total kemampuan berpikir matematis siswa dari hasil skor tes siklus I dan tes siklus II disajikan dalam diagram berikut:

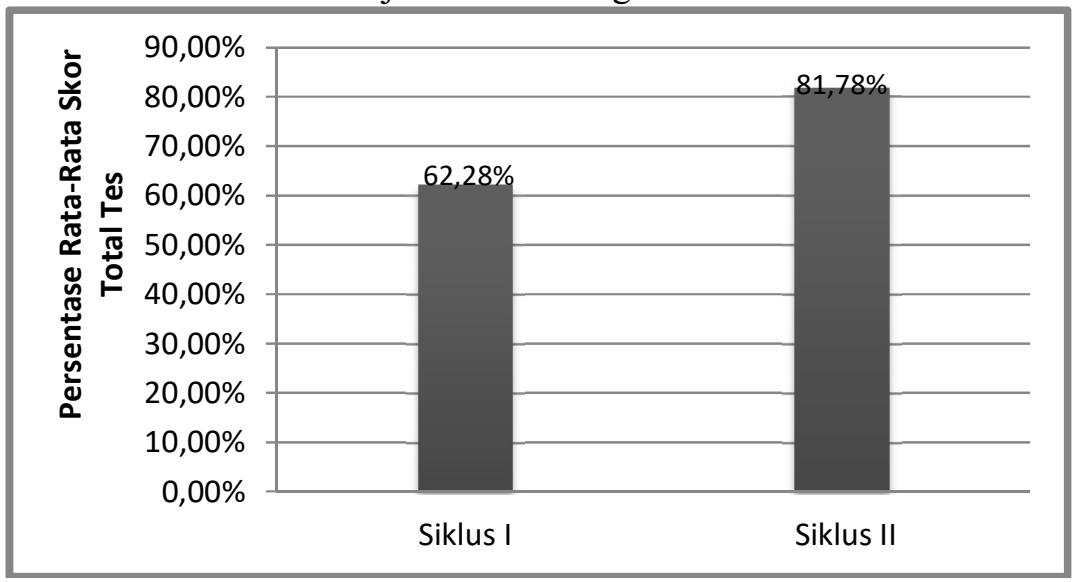

Gambar 2. Diagram Persentase Rata-Rata Skor Total Tes Siklus I dan Siklus II

Berdasarkan analisis data diperoleh bahwa rata-rata skor total kemampuan berpikir matematis siswa pada siklus I adalah 62,28 dari skor maksimal yang mungkin yaitu 100 . Dengan demikian persentase rata-rata tingkat kemampuan berpikir matematis siswa kelas VIII B adalah 62,28\%. Berdasarkan kriteria persentase hasil skor tes kemampuan berpikir 
matematis siswa, maka hasil tes pada siklus I termasuk pada kualifikasi sedang. Berdasarkan analisis hasil tes pada siklus II, didapat rata-rata skor total kemampuan berpikir matematis siswa pada siklus II adalah 81,78 dari skor maksimal yang mungkin yaitu 100. Dengan demikian persentase rata-rata tingkat kemampuan berpikir matematis siswa kelas VIII B dari hasil tes pada siklus II adalah 81,78 \%. Hasil ini berdasarkan kriteria persentase hasil skor tes kemampuan berpikir matematis siswa termasuk dalam kualifikasi tinggi. Dengan demikian mengacu pada indikator keberhasilan dapat disimpulkan bahwa kemampuan berpikir matematis siswa dapat ditingkatkan melalui penerapan pendekatan matematika realistik.

\section{b. Hasil Observasi}

Analisis hasil observasi keterlaksanaan pembelajaran menunjukkan bahwa pelaksanaan tindakan dengan menggunakan pendekatan matematika realistik terlaksana dengan baik. Hal ini ditunjukkan dengan persentase keterlaksanaan pembelajaran pada siklus I dan siklus II termasuk dalam kualifikasi tinggi yaitu 88,24\% dan 97,06\%. Pada siklus I baik pertemuan ke-1 maupun pertemuan ke-2 keterlaksanaan pembelajaran mencapai 88,24\%, sedangkan pada siklus II pertemuan ke-1 mencapai $100 \%$ dan pertemuan ke-2 mencapai $94,12 \%$.

\section{c. Hasil Angket}

Berdasarkan analisis hasil angket diperoleh rata-rata skor angket pada siklus I adalah 68,53 dari skor maksimal yang mungkin yaitu 128. Dengan demikian persentase rata-rata kemampuan berpikir matematis siswa kelas VIIIB dari hasil angket siswa adalah 53,54\%. Berdasarkan kualifikasi persentase hasil skor angket, maka hasil pada siklus I termasuk pada kualifikasi sedang. Berdasarkan analisis hasil angket pada siklus II, didapat rata-rata skor angket adalah 83,06 dari skor maksimal yang mungkin yaitu 128. Dengan demikian persentase rata-rata tingkat kemampuan berpikir matematis siswa kelas VIIIB dari hasil angket siswa pada siklus II adalah $64,89 \%$. Hasil ini berdasarkan kualifikasi persentase hasil skor angket respon siswa termasuk dalam kualifikasi sedang.

Berikut disajikan diagram persentase skor angket respon siswa pada siklus I dan siklus II berdasarkan aspek kemampuan berpikir matematis:

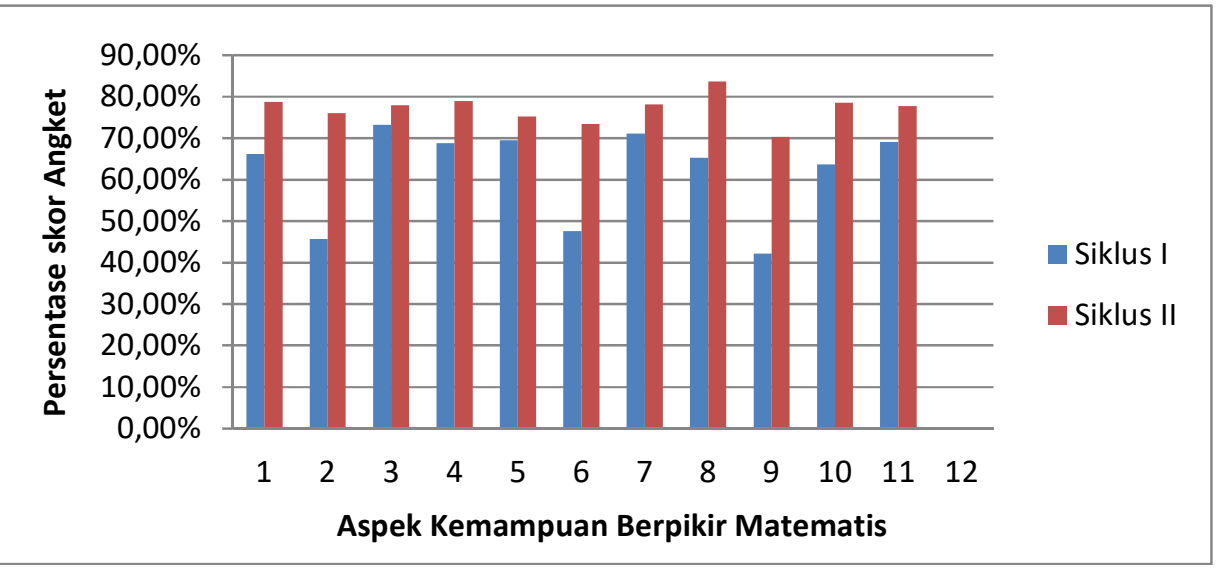

Gambar 3. Diagram Persentase Skor Angket Respon Siswa Siklus I dan Siklus II

\section{d. Hasil Wawancara}

Hasil wawancara dengan siswa dapat disimpulkan sebagai berikut: 
1) Siswa merasa senang mengikuti pembelajaran matematika menggunakan pendekatan matematika realistik. Hal tersebut karena siswa banyak terlibat dalam pembelajaran yang berlangsung yaitu pada saat diskusi kelompok dan presentasi hasil diskusi kelompok.

2) Ketika siswa mendapatkan kesulitan dalam diskusi kelompok, siswa bertanya pada teman dahulu, kalau teman-teman juga tidak bisa kemudian bertanya kepada guru.

3) Siswa lebih mudah dalam memahami materi karena materi yang dipelajari dikaitkan dengan hal-hal yang nyata bagi siswa, antara lain melalui LKS dan praktek menemukan konsep menggunakan benda-benda.

4) Siswa lebih mudah dalam mengerjakan soal-soal tes setelah mengikuti pembelajaran menggunakan pendekatan matematika realistik.

\section{Pembahasan}

Berdasarkan hasil analisis skor tes pada siklus I dan siklus II, diketahui bahwa kemampuan berpikir matematis siswa mengalami peningkatan. Analisis data dari hasil tes pada siklus I diketahui skor minimum yang diperoleh siswa adalah 19 dan skor maksimum yang diperoleh siswa adalah 95. Sedangkan rata-rata skor total kemampuan berpikir matematis siswa pada siklus I adalah 62,28 dari skor maksimal yang mungkin yaitu 100. Dengan demikian persentase rata-rata tingkat kemampuan berpikir matematis siswa kelas VIIIB adalah 62,28\%. Berdasarkan kualifikasi persentase hasil skor tes kemampuan berpikir matematis siswa, maka hasil tes pada siklus I termasuk pada kualifikasi sedang.

Dari analisis data hasil tes pada siklus II diketahui skor minimum yang diperoleh siswa adalah 41, skor maksimum yang diperoleh siswa adalah 100, serta rata-rata skor total kemampuan berpikir matematis siswa pada siklus II adalah 81,78 dari skor maksimal yang mungkin yaitu 100. Dengan demikian persentase rata-rata tingkat kemampuan berpikir matematis siswa kelas VIII B dari hasil tes pada siklus II adalah 81,78 \%. Hasil ini berdasarkan kualifikasi persentase hasil skor tes kemampuan berpikir matematis siswa maka termasuk dalam kualifikasi tinggi. Dengan demikian dapat disimpulkan bahwa kemampuan berpikir matematis siswa dapat ditingkatkan melalui penerapan pendekatan matematika realistik.

Berdasarkan data yang diperoleh dari hasil observasi, catatan lapangan, angket, wawancara, tes siklus I dan siklus II, serta dokumentasi, peneliti menyimpulkan bahwa kegiatan pembelajaran matematika melalui penerapan pendekatan matematika realistik di kelas VIII B SMP Negeri 2 Giriwoyo terlaksana sesuai rencana yang telah disusun. Selain itu, tujuan dari tindakan yang dilakukan yaitu untuk meningkatkan kemampuan berpikir matematis siswa tercapai.

\section{KESIMPULAN}

Berdasarkan hasil penelitian dan pembahasan, dapat disimpulkan bahwa Pembelajaran matematika melalui penerapan pendekatan matematika realistik dapat meningkatkan kemampuan berpikir matematis siswa kelas VIII B SMP Negeri 2 Giriwoyo.

Selanjutnya, mengacu pada temuan dalam penelitian ini, ada beberapa saran yang perlu dipertimbangkan dalam pelaksanaan pembelajaran matematika yaitu:

a. Pembelajaran matematika melalui pendekatan matematika realistik yang telah dilaksanakan hendaknya diterapkan secara kontinu.

b. Pembelajaran melalui pendekatan matematika realistik membutuhkan kreativitas dari guru untuk mengembangkan materi menggunakan permasalahan dalam 
kehidupan sehari-hari dan juga alat peraga yang mendukung sehingga harus memperhatikan karakteristik pendekatan matematika realistik.

c. Penerapan pendekatan matematika realistik membutuhkan manajemen waktu yang baik, sehingga diperlukan perencanaan kegiatan pembelajaran dengan baik supaya penggunaan waktu saat pembelajaran dapat lebih efektif.

d. Bagi seluruh pihak, agar terus berusaha untuk mengembangkan dan mencari inovasi kreativitas pembelajaran matematika terutama yang berkaitan dengan pendekatan matematika realistik.

\section{REFERENSI}

Balitbang Depdiknas. (2003). Standar Kompetensi Mata pelajaran Matematika. Jakarta: Pusat Kurikulum Balitbang Depdiknas.

Erman Suherman, dkk. (2003). Strategi Pembelajaran Matematika Kontemporer. Bandung: Universitas Pendidikan Indonesia.

(2008). Model Belajar dan Pembelajaran Berorientasi Kompetensi Siswa. Bandung: Universitas Pendidikan Indonesia.

Frederick H.Bell. (1994). Teaching and Learning Mathematics. University of Pitsburgh: Wm.C.Brown Company Publishers.

Hammad Fithry Ramadhan. Pendidikan Matematika Realistik Indonesia (PMRI). http://h4mm4d.wordpress.com/2009/02/27/pendidikan-matematika-realistikindonesia-pmri-indonesia/ (Diakses tanggal 10 Agustus 2009).

James M. Royer. (2003). Mathematical Cognition. University of Massachusetts.

Marpaung. (2001). Pembelajaran Realistik dan Sani dalam Pembelajaran Matematika. Makalah disajikan dalam Seminar Matematika di USD.

(2009). Meningkatkan Kualitas Pendidikan dengan PMRI. http://www.republika.co.id/ber 128 70/Meningkatkan_Kualitas_Pendidikan dengan_PMRI (Diakses tanggal i 8 Agustus 2009).

Morris, Lynn Lyon and Gibbon, Carol Tailor Fitz. (1986). How To Measure Achievement. Beverly Hill, London: Sage Publicity.

Norman K. Densin and Yvonnas S. Lincoln. (2005). The Sage Handbook Of Qualitative Research Third Edition. United Kingdom: Sage Publication, Inc. http://books.google.co.id/books?id=X85J8ipMpZEC\&pg=PA559\&dq=Class + Action + Research + Kemmis + and $+\mathrm{Mc}+$ Taggart\& $\mathrm{cd}=1 \# \mathrm{v}=$ onepage $\& \mathrm{q} \& \mathrm{f}=$ false. (Diakses tanggal 04 Mei 2010)

R.K. Sembiring. (2008). Majalah PMRI Volume VI No.4 2008. Bandung: Institut Pengembangan PMRI-FMIPA ITB. 
Pendekatan Matematika Realistik Untuk Meningkatkan Kemampuan Berpikir Matematis Siswa

Nurmudi

Ruseffendi, E.T. (2006). Pengantar Kepada Guru Mengembangkan Kompetensinya dalam Pengajaran Matematika untuk Meningkatkan CBSA. Bandung: Tarsito.

Shigeo Katagiri. (2004). Mathematical Thinking and How to Teach It. Tokyo: Meijitosyo Publishers. Copyright of English version has CRICED, University of Tsukuba. http://www.criced.tsukuba.ac.jp/math/apec/apec 2007/paper_pdf/Shigeo\%20Katagiri.pdf. (Diakses tanggal 10 Agustus 2009).

Sumitro, Dwi S., T. Sulistyono, dkk. (2006). Pengantar Ilmu Pendidikan. Yogyakarta: Fakultas Ilmu Pendidikan Universitas Negeri Yogyakarta.

Sutarto Hadi. (2002). Effective Teacher Profesional Development for the Implementation of Realistic Mathematics Education in Indonesia. Disertasi. Enschede: Print Partners Ipskamp. (2005). Pendidikan Matematika Realistik. Banjarmasin: Tulip. 